Article

\title{
Fish Community Responses to Human-Induced Stresses in the Lower Mekong Basin
}

\author{
Vanna Nuon ${ }^{1,2, *}$, Sovan Lek ${ }^{3,4}$, Peng Bun Ngor ${ }^{4,5}\left(\mathbb{C}\right.$, Nam So $^{1,4}$ and Gaël Grenouillet ${ }^{3,6}$ \\ 1 Mekong River Commission Secretariat, P.O. Box 6101, 184 Fa Ngoum Road, Unit 18, Vientiane 01000, Laos; \\ sonam@mrcmekong.org \\ 2 Cambodia National Mekong Committee, No. 576, National Road No. 2, Sangkat Chak Angre Krom, \\ Khan Meanchey, Phnom Penh 12300, Cambodia \\ 3 Laboratoire Evolution et Diversité Biologique, UMR5174, Université de Toulouse III Paul Sabatier, CNRS, \\ IRD, 31062 Toulouse, France; sovan.lek@univ-tlse3.fr (S.L.); gael.grenouillet@univ-tlse3.fr (G.G.) \\ 4 Inland Fisheries Research and Development Institute, Fisheries Administration, No. 186, Preah Norodom \\ Blvd., P.O. Box 582, Phnom Penh 12300, Cambodia; pengbun.ngor@gmail.com \\ 5 Wonders of the Mekong Project, c/o Inland Fisheries Research and Development Institute, Fisheries \\ Administration, No. 186, Preah Norodom Blvd., P.O. Box 582, Phnom Penh 12300, Cambodia \\ 6 Institut Universitaire de France, 75231 Paris, France \\ * Correspondence: vannanuon88@gmail.com
}

Received: 8 October 2020; Accepted: 11 December 2020; Published: 15 December 2020

check for updates

\begin{abstract}
The Mekong River is one of the world's largest rivers and has an annual captured fish production of about 2.3 million tonnes, equivalent to around 11 billion USD. Although the Mekong provides important ecological and socioeconomic benefits to millions of people, it is facing intensive change due to anthropogenic stressors. Therefore, it is necessary to understand the changes to the spatiotemporal fish communities to inform sustainable fisheries management. Here, we aimed to characterize patterns of the fish communities and identify the ecological status of each fish community using daily catch data from 2007 to 2018 at 25 monitoring sites in the Lower Mekong Basin (LMB). The collected data were classified by a self-organizing map into four main groups. Group 4 represented the lower Vietnam Mekong Delta (VMD), while groups 1, 2, and 3 were subdivided into subgroups 1a (upper LMB), 1b (upper and middle LMB), 2a (Mekong River below the Khone Falls and Sesan River), 2b (Mekong River below the Khone Falls and Sekong, Sesan and Srepok (3S) Rivers), 3a (Floodplain-Tonle Sap and Songkhram) and 3b (upper VMD). Among the 571 species recorded, 119 were identified as indicator species. Based on the abundance and biomass comparison curves, the fish community of $2 \mathrm{~b}$ was in a healthier condition with a positive $\mathrm{W}$-statistic value while the rest had a negative $\mathrm{W}$-statistic value. The highest species richness and diversity were observed in $3 \mathrm{a}$ and $2 \mathrm{~b}$, so these subgroups deserve high management and conservation priority. Likewise, 1a should also be considered as a high priority area since it harbors several endangered and long-distant migratory fishes. It was also noticed that the fish communities of groups 3 and 4 , located far from the hydropower dams, remained mostly unchanged compared to those of groups 1 and 2, close to the mainstream and tributary dams in the upper LMB and 3S Rivers.
\end{abstract}

Keywords: self-organizing map; species diversity; indicator species; fish community structure; rarefaction curve; $\mathrm{ABC}$ curve; fish community health

\section{Introduction}

Freshwater ecosystems are under threat from various stressors, such as land degradation, pollution, water extraction, and dam construction [1-5]. Anthropogenic hydrological changes have modified freshwater ecosystems and altered the physical characteristics of the aquatic habitat, strongly affecting 
the structure and composition of fish communities [6-8]. Additionally, overfishing by both legal and illegal fishers acts as a key factor that may dramatically lessen fish populations $[9,10]$.

An assessment of the fish community structure is useful to evaluate the biotic integrity in rivers $[11,12]$. Fish are very sensitive to changes in the aquatic environment due to their dependence on both the physical environment and the other aquatic organisms, so a fish community with an altered composition may indicate a change in the quality of the environment. Likewise, the health of each fish community can reflect the status of the entire aquatic community [13-15].

The Mekong River, one of the world's largest rivers, supports nearly 70 million people who partly or entirely rely on it for their subsistence. Further, the Mekong River is one of the 35 biodiversity hotspots globally, providing significant ecological services to fish, plants, and mollusks, as well as a number of critically endangered species, such as the Irrawaddy dolphin and the Mekong giant catfish [16-20]. The Mekong River basin hosts nearly 1148 fish species [21] and is ranked third globally after the Amazon River Basin (2406 species) [22] and Congo River Basin (over 1200 species) [23]. Moreover, the Lower Mekong Basin (LMB) annual captured fish production yielded about 2.3 million tonnes, or about $20 \%$ of the inland captured fisheries production globally, which is valued at around 11 billion USD [21]. Although the Mekong River provides massive ecological and socioeconomic benefits, its ecosystem is facing intense pressure due to anthropogenic induced stressors, such as hydropower, irrigation, navigation, sand mining, and overfishing [24-27]. Consequently, it may lead to changes in fish diversity and community structure. Data and information reflecting these changes are crucial in assisting planners (i.e., river basin management planners) to make trade-off decisions for ecologically sustainable river management [28,29]. However, only one large-scale study on patterns of fish diversity and assemblage structures in the LMB [30] has been conducted to date. In addition, their study covered only the Mekong mainstream, excluding the key tributary habitats of the LMB, for example, Tonle Sap River and Lake, and Sekong, Sesan, and Srepok (3S) Rivers, and inter-annual changes in the fish community. In addition, the study was based on data collected from December 2000 to November 2001, but given that the LMB has undergone rapid changes from regional development over the past two decades, the analysis needs to be updated using more recent data. Therefore, the objectives of this study were: (i) to describe spatial and temporal patterns in fish communities and define community groups, (ii) to identify indicator species characterizing each community group, and (iii) to assess the ecological status of fish communities in each group as a response to anthropogenic activities. Our study contributes to the knowledge of long-term changes and health of the fish communities in the LMB as a factor to be included in the decision-making process for effective planning and sustainable management of the LMB fisheries resources.

\section{Materials and Methods}

\subsection{Study Area}

The Mekong is a trans-boundary river with a length of $4763 \mathrm{~km}$. The river rises onto the Tibetan plateau and runs through China, Myanmar, Lao People's Democratic Republic (Lao PDR), Thailand, Cambodia, and Viet Nam. The catchment has an area of $810,000 \mathrm{~km}^{2}$, discharging on average $446 \mathrm{~km}^{3}$ of water annually [21]. The Mekong Basin has been split into two sections, the Upper and Lower Mekong Basins. The Upper Mekong Basin runs through China and Myanmar, covering a total surface area of $186,356 \mathrm{~km}^{2}$, making up $23.2 \%$ of the total basin area and contributing $15-20 \%$ of the water flowing into the Mekong River [21,31]. The LMB comprises about 76\% of the whole Mekong River Basin (Figure 1) covering a large part of land area of Lao PDR and Cambodia, the northern and northeast regions of Thailand, and the Central Highlands and Mekong Delta of Viet Nam. 


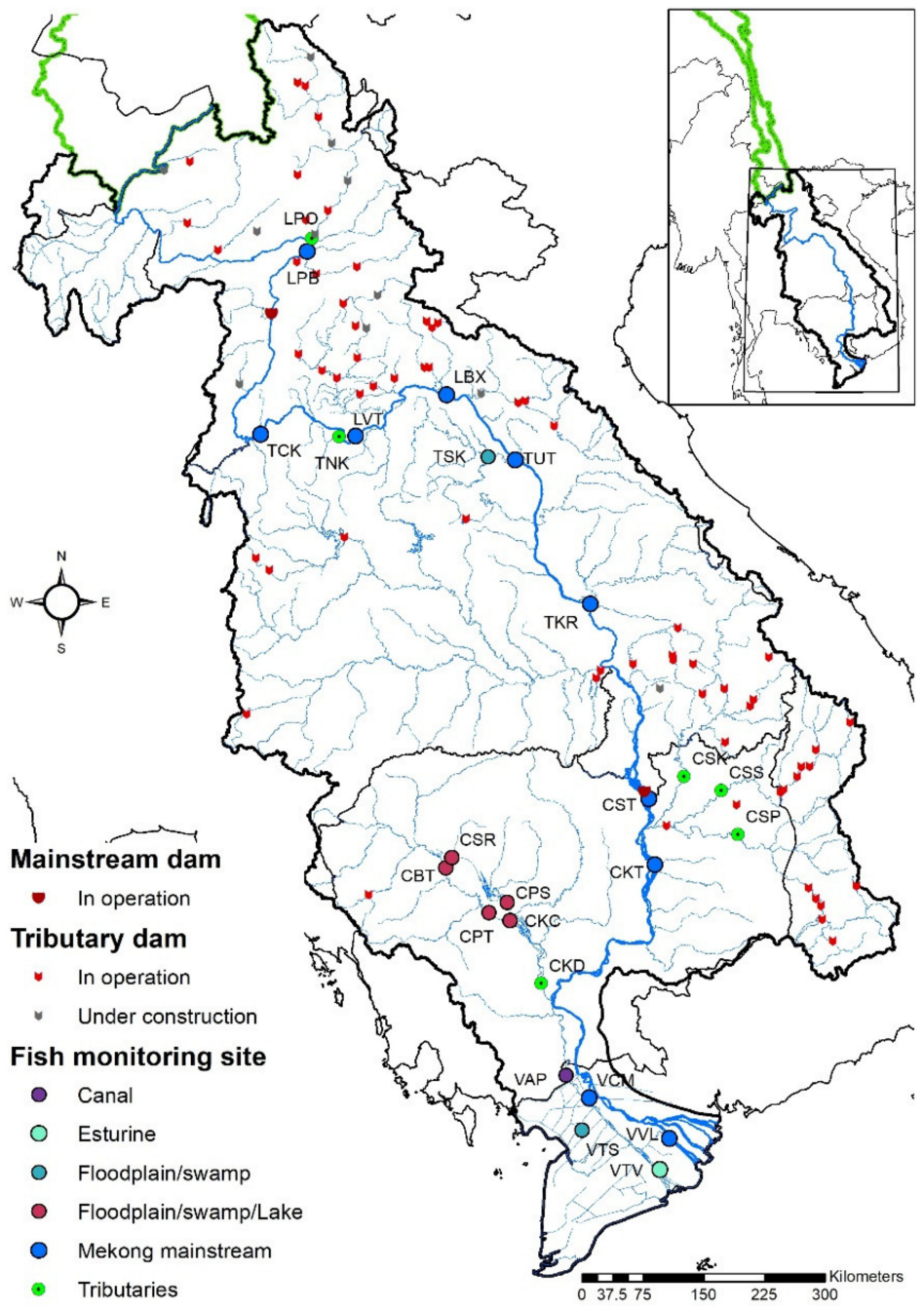

Figure 1. Distribution of monitoring sites and hydropower dams in the Lower Mekong River (Data source: MRC Hydropower Project Database 2019). Site names: LPB = Luangphrabang; LPO = Pak Ou; LVT = Vientiane; $\mathrm{LBX}=$ Borikhamxay; TCK = Loei; TNK = Nong Khai; TSK = Sisongkhram; TUT = Tha Uthen; $\mathrm{TKR}=$ Ubon Ratchathani; CST = Stung Treng; CSK = Sekong; CSS = Sesan; CSP = Srepok; CKT = Kratie; $\mathrm{CSR}=$ Siem Reap; $\mathrm{CBT}=$ Battambang; $\mathrm{CPT}=$ Kompong Thom; $\mathrm{CPS}=$ Pursat; $\mathrm{CKC}=$ Kompong Chhang; $\mathrm{CKD}=$ Kandal; VAP = An Phu; VCM = Cho Moi; VTS = Thoai Son; VVL = Vinh Long; VTV = Tra Vinh.

\subsection{Data Collection}

Fish data were collected through fisheries-dependent monitoring supported by the Mekong River Commission (MRC) and implemented by national teams from fisheries-related agencies in the four MRC Member Countries (Cambodia, Lao PDR, Thailand, and Viet Nam). The daily fish catch data were collected from 25 monitoring sites spread across the LMB (Figure 1), and monitoring was based on the MRC's standard sampling procedures for fish catch monitoring in the LMB [32,33]. Most data were collected between 2007 and 2018, except the data from the five sites in the provinces around Tonle Sap Lake (TSL) of Cambodia which was between 2012 and 2018. Moreover, the data have some gaps due to financial shortages during certain years, especially between 2014 and 2016 (Figure S1). Although these time-series data are incomplete, they can capture changes in the status of fish communities over the 12-year period induced by anthropologic activities. Each site consists of three fishers who collected and recorded their daily fish catches in a logbook, including fish weight, total weight, number of fish and fishing effort. This is a multi-gear fishery, but the most common gear type used was stationary gillnet (61\%), followed by drift gillnet (13\%) and trammel net $(12 \%)$. The captured fish were identified 
to the species level using an updated species list (1148 species) from the MRC Fisheries Database (2015). Based on the updated species list, fish species were ecologically categorized into 11 guilds (Table S1). The key advantage of this sampling design is the relatively low cost, but it still provides a continuous and consistent long-term record of fish catch data. The fish catch data recorded in the logbooks were collected quarterly, checked, and entered into the national databases by the national teams of each country. Then, the four national databases were sent to the fisheries monitoring specialists of the MRC Secretariat twice a year for error checking and synchronizing into a regional fish monitoring database.

\subsection{Statistical Analysis}

Daily fish catch data (abundance and biomass) by the three fishers at each monitoring site were used for this study. They were computed as daily mean data and then aggregated into yearly relative fish abundance and biomass data by species over the 12-year study period.

\subsubsection{Fish Community Structures and Spatiotemporal Variations}

A self-organizing map (SOM) is a type of an unsupervised artificial neural network aiming to visualize similar items in a dataset, and also to reduce multidimensional data to fewer dimensions [34]. SOM was used since it can be more efficient with large and complex ecological data, especially non-linear, heterogeneous, and missing data. In addition, it is able to maintain spatial and temporal variations, and includes both dominant and rare species [35]. There is also evidence that SOM could work better than other conventional methods that use ecological data, such as polar ordination, principal component analysis, correspondent analysis, and non-metric multidimensional scaling [36,37]. The structure of the SOM is comprised of two layers-input and output. The input layer is formed by a set of neurons, which are input values from the data matrix (212 samples and 571 species), while the output layer made by output neurons is arranged into a hexagonal lattice for better data visualization. The hexagonal lattice was applied in this study since it does not favor horizontal or vertical directions as much as rectangular [38]. The selection of SOM size was conducted by examining a number of SOM sizes (row $\times$ column) $-12 \times 6,12 \times 7,13 \times 5$, and $13 \times 6$ - close to Vesanto's heuristic rule $(5 \times \sqrt{\text { number of samples }})$ [39]. A SOM size of 13 rows and 6 columns was selected as it provided a clear-cut classification among SOM groups. Yearly relative fish abundance data were Hellinger-transformed prior to SOM computation, and then SOM was computed through the "som" function of the "kohonen" package in R [40]. Furthermore, during the SOM learning process, Euclidean distance was used since it provides equal importance to species with high or low relative total abundances [41]. We also used Ward's hierarchical clustering on weight vectors of SOM to identify boundaries of clusters in the SOM map defining groups of sites or fish communities. In addition, the SOM map was used to visualize the probability of occurrence for the indicator species in each SOM group (Figure S4).

After fish samples were classified into SOM groups, a sample-based rarefaction curve was used to compare the species richness and the inverse Simpson diversity index among SOM groups. The rarefaction method allows researchers to make a fair comparison among sites where there has been a different sampling effort [42]. Also, the rarefaction curve was computed by the "iNEXT" package in $\mathrm{R}$ [43] with a doubling in sample size for the extrapolation curve and 500 bootstraps for estimating 95\% confidence intervals [44]. Moreover, significant differences at a level $<5 \%$ in richness and in the diversity index among groups were observed through nonoverlapping 95\% confidence intervals. Moreover, total beta diversity ( $\left.\mathrm{BD}_{\text {Total }}\right)$ was used to investigate the temporal variation in species composition among survey years within each SOM group. BD $\mathrm{B}_{\text {Total }}$ was partitioned into temporal local contributions to beta diversity (LCBD) to indicate and test which years between 2007 and 2018 of each SOM group significantly contribute to the overall variation in species composition. The significant LCBD indices show the fish community's uniqueness in certain years and can be linked

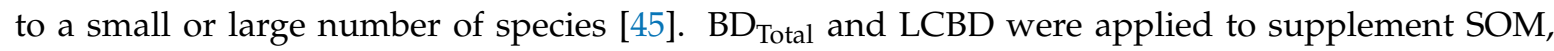
which mainly captures the spatial pattern of the fish communities. The relative fish abundance data 
were classified by SOM groups and then Hellinger-transformed $[45,46]$ before estimating the BD Total $_{\text {. }}$ The value of $\mathrm{BD}_{\text {Total }}$ ranges from 0 to 1 . When the species composition is completely different for all survey years, $\mathrm{BD}_{\text {Total }}$ is equivalent to 1 . $\mathrm{BD}_{\text {Total }}$ was calculated by the "beta.div" function of the "adespatial" package with 999 permutations in R [47].

Lastly, indicator species were determined according to an ecological preference of the species to spatially differentiate the characteristics of each SOM group; the indicator species was also computed (999 permutations) by the "multipatt" function from the "indicspecies" package in R [48-50].

\subsubsection{Status of Fish Communities in the LMB}

The status of the fish communities was assessed using the abundance and biomass comparison (ABC) curve [51], which was initially developed for detecting disturbances to marine macrobenthic communities. Theoretically, the ABC curve adopts a classical evolutionary theory of r- and K-selection. A stable community that is undisturbed is dominated by K-selected species, which are slow-growing, have a large body size, are long-lived and mature later in life [29,51]. Thus, the curve of the cumulative biomass would be higher than that of the cumulative abundance. On the contrary, a highly disturbed community is dominated by r-selected species that are fast-growing, have a small body size, are short-lived and are opportunistic. As a result, the cumulative abundance curve would be higher than the cumulative biomass curve. For a moderately disturbed community, both curves would closely parallel and may cross each other. This method is useful for detecting human-induced stressors on the river fish community [52]. Another advantage of this method is that it enables the assessment of the status of the community when the data of both relative biomass and abundance are available for the same time and place without the need for a baseline, or control samples, in time or space [53].

The yearly fish catch data (relative abundance and biomass) were clustered by the SOM groups, then, both relative abundance and biomass for each sample (site and year) were accumulated for each SOM group. Combined k-dominance curves of relative abundance and biomass were created following the ABC curves method [51], where species were ranked in the order of importance on the $x$-axis (logarithmic scale) with percent dominance on the $y$-axis (cumulative scale). The distance between the abundance curve and the biomass curve is determined by $\mathrm{W}$-statistics ranging from -1 and +1 , and was calculated using the following formula. ABC curves were developed, and the W-statistic was computed using the "abc" function of "forams" package in R [54].

$$
W=\sum_{i=1}^{s} \frac{\left(B_{i}-A_{i}\right)}{[50(S-1)]}
$$

where $S$ is the number of species, $A_{i}$ is an accumulative abundance value of each species rank $i$, and $B_{i}$ is an accumulative biomass value of each species rank $i$.

\subsubsection{Classification of Fish-Bodied Size}

The fish-bodied size in the LMB was categorized into four groups, namely small $(\leq 25 \mathrm{~cm})$, medium (26-60 cm), large $(61-99 \mathrm{~cm})$, and giant $(\geq 100 \mathrm{~cm})$ according to the total length of the fish [55]. In this study, the total length of the fish caught was obtained from the Mekong Fish Database [56] and FishBase [57], and classified into fish-bodied size groups. To visualize the dominant fish catch by SOM groups, yearly relative fish abundance data were clustered by SOM groups and then plotted according to fish-bodied size (Figure S3).

\section{Results}

\subsection{Fish Community Structures}

Across the 12-year study period, a total of 571 fish species $(28,046,065$ individuals) were collected from 25 sampling sites; the species belonged to 76 families within 20 orders. Fish species belonging to 
11 out of the 76 families accounted for $64 \%$ of the total number of species, and the family Cyprinidae dominated the catch, making up $31 \%$ of the total number of species. Among the 571 species, four were categorized as critically endangered, 12 as endangered, and 18 as vulnerable (Table 1).

Table 1. Threatened species categorized by IUNC Red List: CR = critically endangered; EN = endangered; $\mathrm{VU}=$ vulnerable.

\begin{tabular}{|c|c|c|c|}
\hline Order & Family & Scientific Name & Category \\
\hline Cypriniformes & Cyprinidae & Aaptosyax grypus & CR \\
\hline Cypriniformes & Cyprinidae & Catlocarpio siamensis & CR \\
\hline Siluriformes & Pangasiidae & Pangasianodon gigas & CR \\
\hline Siluriformes & Pangasiidae & Pangasius sanitwongsei & CR \\
\hline Cypriniformes & Cyprinidae & Poropuntius deauratus & EN \\
\hline Siluriformes & Pangasiidae & Pangasianodon hypophthalmus & EN \\
\hline Cypriniformes & Cyprinidae & Probarbus jullieni & EN \\
\hline Cypriniformes & Cyprinidae & Probarbus labeamajor & EN \\
\hline Osteoglossiformes & Osteoglossidae & Scleropages formosus & EN \\
\hline Cypriniformes & Cyprinidae & Luciocyprinus striolatus & EN \\
\hline Cypriniformes & Cyprinidae & Poropuntius solitus & EN \\
\hline Myliobatiformes & Dasyatidae & Dasyatis laosensis & EN \\
\hline Cypriniformes & Cyprinidae & Poropuntius bolovenensis & EN \\
\hline Myliobatiformes & Dasyatidae & Himantura oxyrhynchus & EN \\
\hline Cypriniformes & Cyprinidae & Poropuntius consternans & EN \\
\hline Myliobatiformes & Dasyatidae & Himantura signifer & EN \\
\hline Cypriniformes & Cyprinidae & Hypsibarbus lagleri & VU \\
\hline Siluriformes & Pangasiidae & Pangasius krempfi & VU \\
\hline Cypriniformes & Cyprinidae & Cirrhinus microlepis & VU \\
\hline Cypriniformes & Cyprinidae & Scaphognathops bandanensis & VU \\
\hline Perciformes & Osphronemidae & Osphronemus exodon & VU \\
\hline Perciformes & Datnioididae & Datnioides undecimradiatus & VU \\
\hline Cypriniformes & Cyprinidae & Labeo pierrei & VU \\
\hline Cypriniformes & Cyprinidae & Bangana behri & VU \\
\hline Clupeiformes & Clupeidae & Tenualosa thibaudeaui & VU \\
\hline Cypriniformes & Cyprinidae & Epalzeorhynchos munense & VU \\
\hline Cypriniformes & Cyprinidae & Poropuntius speleops & VU \\
\hline Cypriniformes & Cobitidae & Botia nigrolineata & VU \\
\hline Cypriniformes & Cobitidae & Serpenticobitis cingulata & VU \\
\hline Cypriniformes & Cyprinidae & Tor ater & VU \\
\hline Cypriniformes & Cyprinidae & Mystacoleucus lepturus & VU \\
\hline Cypriniformes & Balitoridae & Hemimyzon confluens & VU \\
\hline Cypriniformes & Cyprinidae & Oxygaster pointoni & VU \\
\hline Cypriniformes & Cyprinidae & Troglocyclocheilus khammouanensis & VU \\
\hline
\end{tabular}

From the spatiotemporal fish community data, samples were ordinated by SOM into a two-dimensional map, and the SOM units were classified by a hierarchical clustering into four main groups (Figure 2). Group 1 represented the fish community at the upper and middle LMB and split up into two subgroups (1a and 1b). Subgroup 1a consisted of 19 samples from LPB (2008-2014), LPO (2008-2010), LVT (2012 and 2017), and LBX (2008-2013). Subgroup 1b contained all of the samples from TCK, TKR, and TUT, as well as some samples from CKD, LPB, LPO, and LBX for the latest years. Furthermore, four samples of LVT $(2008,2011,2014$, and 2018) were within this subgroup. Group 2, representing the fish community in the Mekong below the Khone Falls and the 3S Rivers, consisted of two subgroups. Subgroup 2a contained almost all of the samples from the early years of the monitoring, including 20 samples from CKT, CST, and CSS at the Mekong below the Khone Falls and Se San River, seven samples from CKD (2008-2015, except 2014) at Tonle Sap River, and three samples from LVT (2009, 2010, and 2013) upstream of the Mekong River in Lao PDR. Subgroup 2b comprised all of the samples from CSK and CSP and four samples from CSS (2015-2018). In addition, six of the samples 
from CST (2010-2018, except 2011-2013) and the other six samples from CKT (2010-2018, except 2011, 2012, and 2016) were assigned to this subgroup. Group 3 characterized the floodplain fish community, and was divided into two subgroups. Subgroup 3a encompassed almost all of the samples from the five sites (CBT, CPS, CPT, CSR, and CKC) of the TSL, all samples from TSK and TNK in northeastern Thailand (including Songkhram floodplain), and two samples from VAP (2017-2018) at the upper Viet Nam Mekong Delta (VMD). Subgroup 3b comprised most of the samples from VAP, VCM, and VTS at upper VMD, plus two samples from CSR (2014 and 2015) at TSL. Among the four main groups, group 4 was the smallest and contained all of the samples from VVL and VTV located at the lower VMD, very close to the sea.

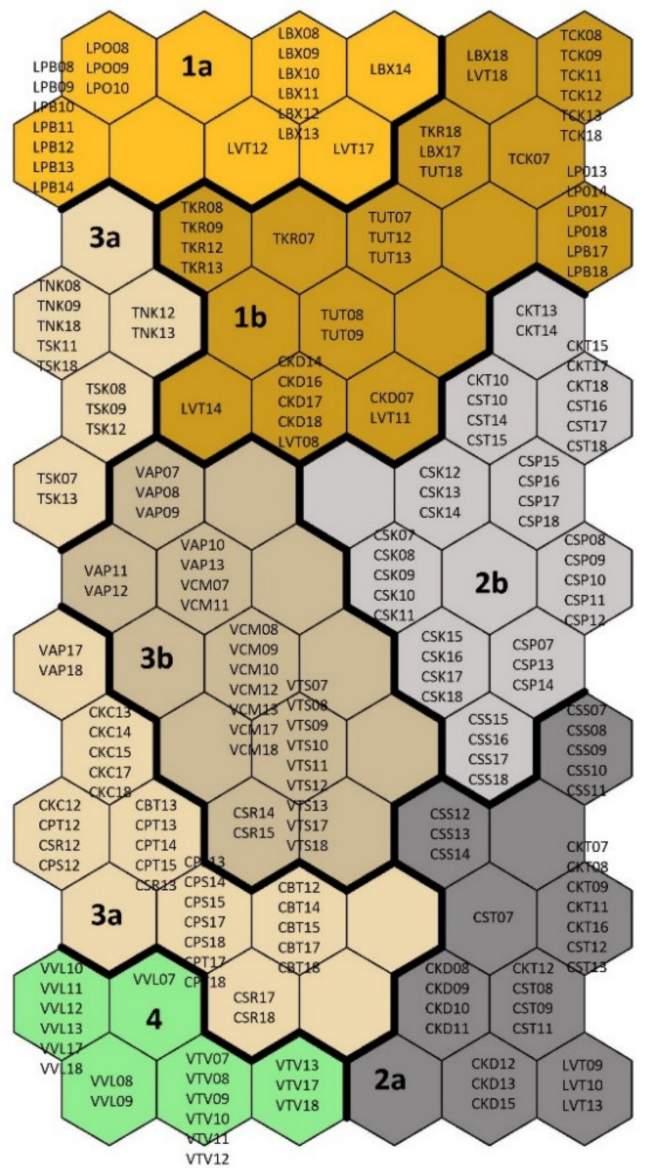

(a)

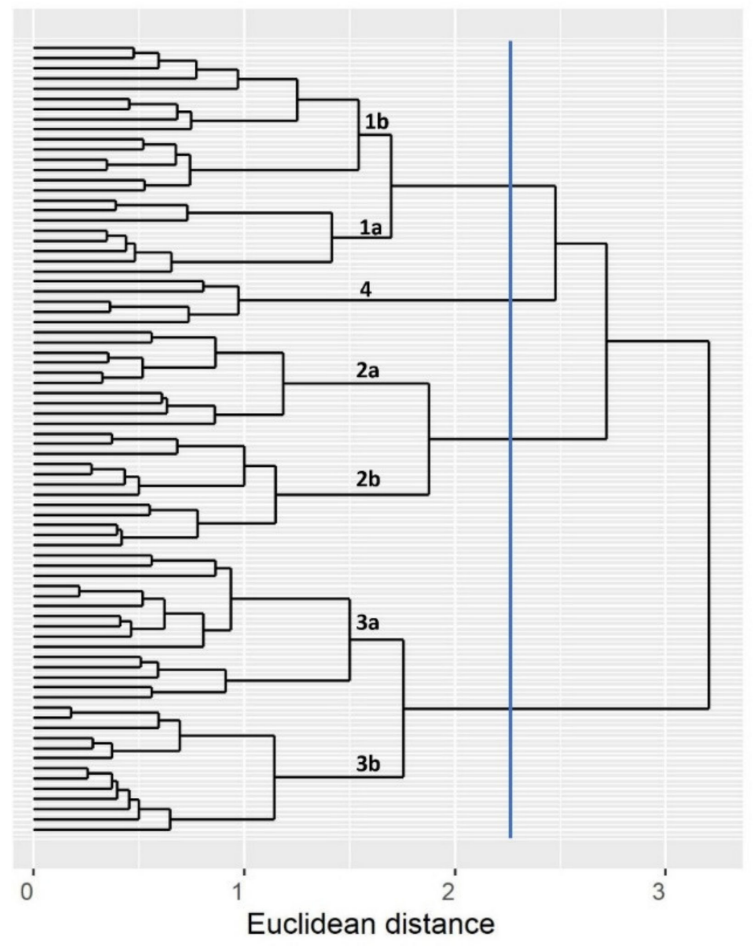

(b)

Figure 2. The output neurons of SOM with the assigned 212 samples from 25 fish monitoring sites: (a) SOM classification based on the similarity of fish composition; and (b) hierarchical clustering according to the similarity between SOM neurons. The four main groups of SOM are marked off by the blue vertical line. The group and their subgroups are labeled based on the longitudinal gradient of the river. Each sample is denoted by a five-character code comprising of three letters identifying the site, with the first character representing the country: $\mathrm{C}$ for Cambodia, $\mathrm{L}$ for Lao PDR, $\mathrm{T}$ for Thailand, and V for Viet Nam. The last two digits of the code indicate the year sampled.

The highest species richness was found in subgroups $2 b$ and $3 a$ (Figure $3 a)$, which were not significantly different, followed by subgroup $2 \mathrm{a}$ and subgroup $1 \mathrm{~b}$. Moreover, subgroup $3 \mathrm{~b}$ and group 4 had a significantly similar species richness, but with lower values than the above-mentioned subgroups. Subgroup 1a showed the lowest species richness. Likewise, the highest diversity index was found for subgroup $2 b$ (Figure $3 b$ ), followed by subgroups $2 a$ and $3 a$ with no significant difference, and subgroup $1 b$. The lowest diversity index was found for subgroups $1 a$ and $3 b$, as well as group 4 . Among the seven 
SOM groups and subgroups, total community variation across years $\left(\mathrm{BD}_{\mathrm{Total}}\right)$ was relatively high for subgroup $1 b(0.53)$ and subgroup 3a (0.45), while the rest ranged from 0.18 to 0.32 (Table S2). For subgroup 1b, the LCBD index was significant in 2012 (Table S2), illustrating that the species composition was significantly different from the other years. The dominant species of that year were Pangasius conchophilus, Garra fasciacauda, and Sikukia gudgeri (Figure S2). In addition, the LCBD indices of subgroup 3a were significantly higher in the early survey years (2007-2009 and 2011). This indicates a compositional heterogeneity of species among the early survey years, as well as between the early survey years and the later ones (2012-2018). The most abundant species of those years with high LCBD indices were Henicorhynchus siamensis, Labiobarbus lineata, and Mystus singaringan in 2007, Parambassis siamensis and Puntius spilopterus in 2008, P. siamensis, P. spilopterus, and Sikukia gudgeri in 2009, and P. spilopterus and Osteochilus schlegeli in 2011 (Figure S2).

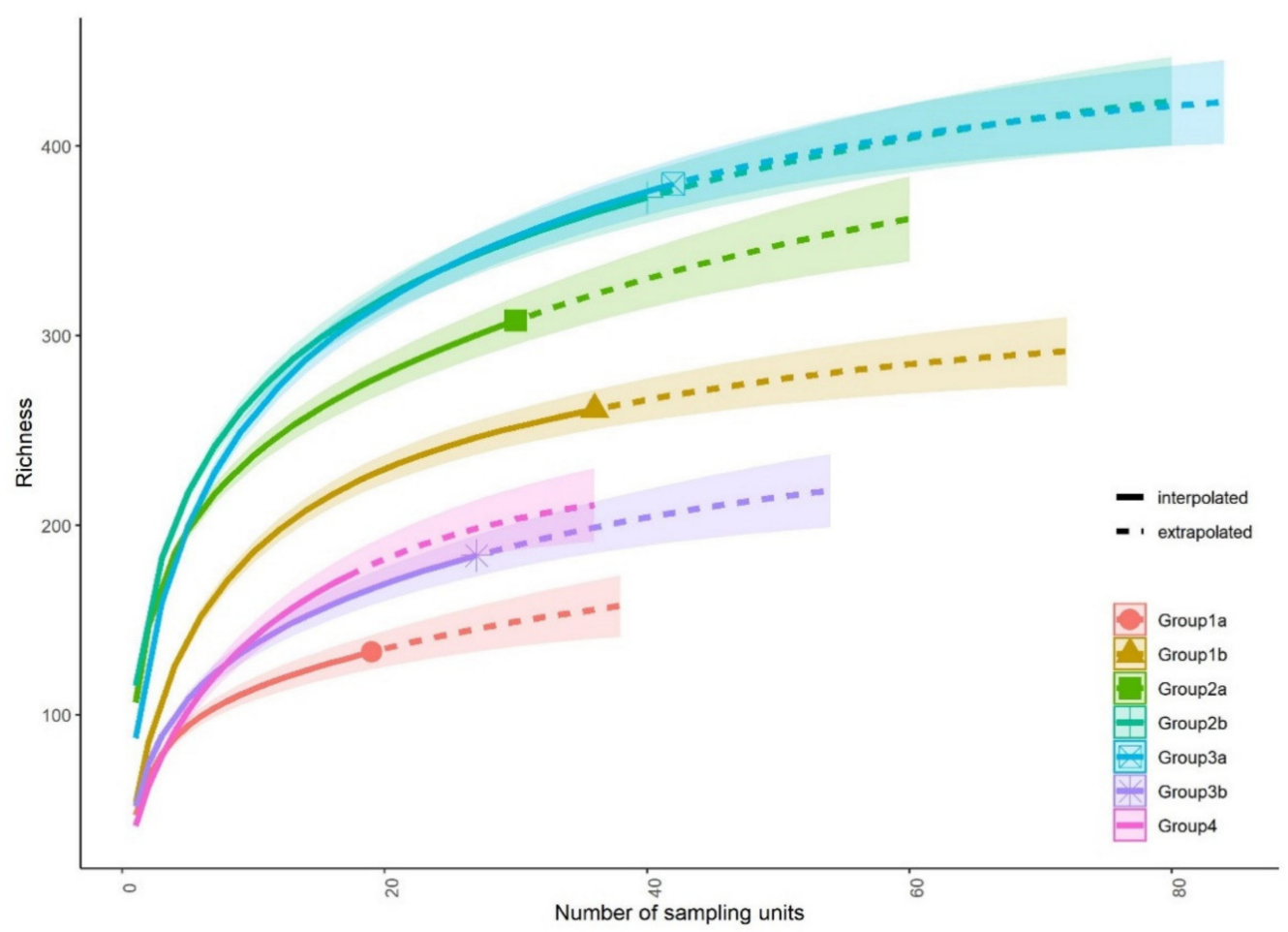

(a)

Figure 3. Cont. 


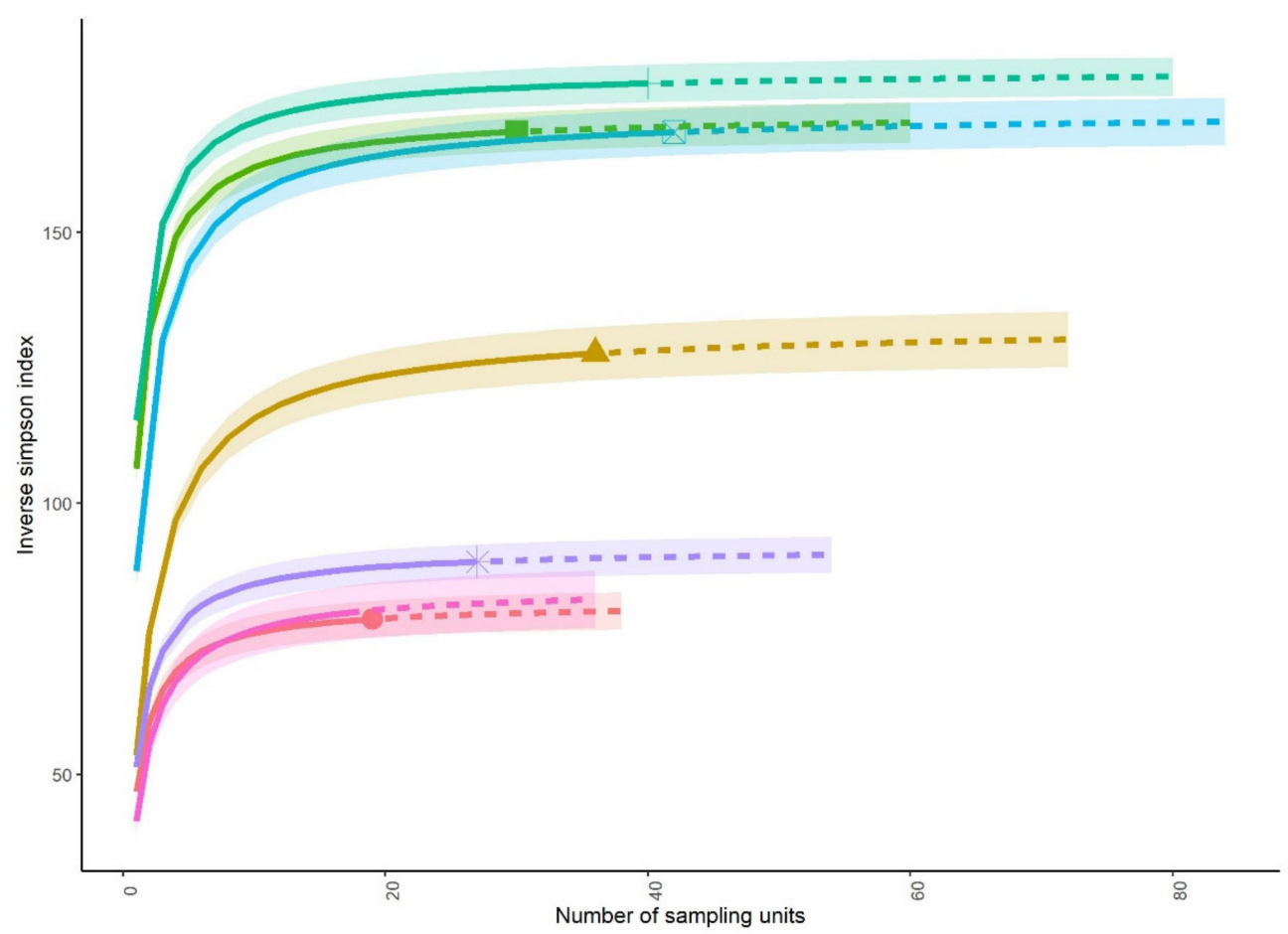

(b)

Figure 3. Rarefaction curves on (a) fish species richness of seven groups and subgroups, and (b) inverse Simpson diversity index of seven groups and subgroups. All extrapolation curves are plotted to a doubling in sample size, and 500 bootstrap replicates are used to estimate $95 \%$ confidence intervals.

\subsection{Indicator Species by Groups}

Among the 571 species, 119 were identified with significant indicator values for the seven SOM groups and subgroups (Table S3). The number of indicator species varied between fish communities from the upper to lower reaches of the LMB, with the largest number being found in subgroup $3 \mathrm{a}$ (43 species), followed by group 4 (39 species), while the lowest number was observed in subgroup $1 \mathrm{~b}$ (4 species). Subgroup 1a was characterized by seven indicator species, of which three species (Belodontichthys dinema, Cyprinus carpio, and Labeo erythropterus) were non-native fishes, two species (Dasyatis laosensis and Hypsibarbus vernayi) were short-distant white fishes, one species (Bagarius yarrelli) was a rhithron resident and another (Pangasianodon gigas) was a long-distant white fish. Subgroup $1 \mathrm{~b}$ was composed of four indicator species, which were short-distant white fishes (Bangana elegans and Helicophagus leptorhynchus) and grey fishes (Neodontobutis aurarmus and Sikukia gudgeri). Five main indicator species for subgroup 2a were grey fishes (Paralaubuca barroni, P. riveroi, and Rasbora aurotaenia) and estuarine residents (Arius argyropleuron and Ophisternon bengalense). Subgroup $2 \mathrm{~b}$ comprised of 15 indicator species categorized into six guilds, of which rhithron residents were a dominant guild with five species (e.g., Onychostoma fusiforme and Neolissochilus stracheyi). Several key indicator species (43 species) representing subgroup 3a belonged to eight guilds, yet it was dominated by short-distant white fishes (e.g., Wallago attu, Albulichthys albuloides, and Kryptopterus micronema) and grey fishes (e.g., Thynnichthys thynnoides, Heterobagrus bocourti, and Mystus atrifasciatus). Subgroup 3b contained six indicator species of short-distant white fishes (Akysis similis and Hypostomus plecostomus), a black fish (Macrognathus siamensis), estuarine residents (Batrachocephalus mino and Eleotris fusca), and a non-native fish (Oreochromis niloticus). Group 4 consisted of 39 indicator species from five guilds, but most species were estuarine residents, such as Osteogeneiosus militaris and Arius maculatus and marine visitors, such as Nibea soldado and Coilia macrognathos. 


\subsection{Status of Fish Communities in the LMB}

The ABC curves showed that only the fish community of subgroup $2 b$ had a positive $W$-statistic $(\mathrm{W}=0.0442)$, while those of subgroups $1 \mathrm{a}, 3 \mathrm{a}, 3 \mathrm{~b}$, and group 4 had small negative $\mathrm{W}$-statistic values (Figure 4 ). The fish communities of the remaining two subgroups ( $1 \mathrm{~b}$ and $2 \mathrm{a}$ ) had relatively large negative $\mathrm{W}$-statistic values, and the distance between the abundance and biomass curves were relatively large. Finally, while the biomass curve of subgroup $2 b$ is above the abundance curve, the other subgroups displayed the opposite pattern.

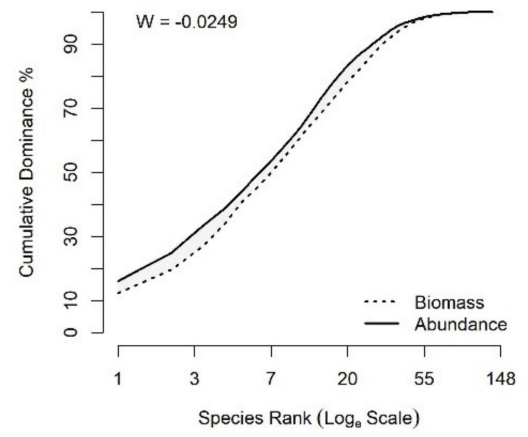

(a)

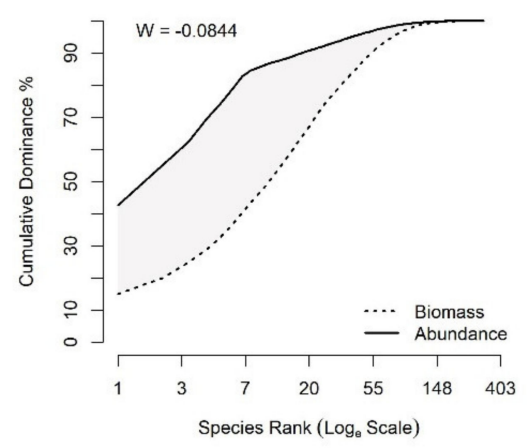

(c)

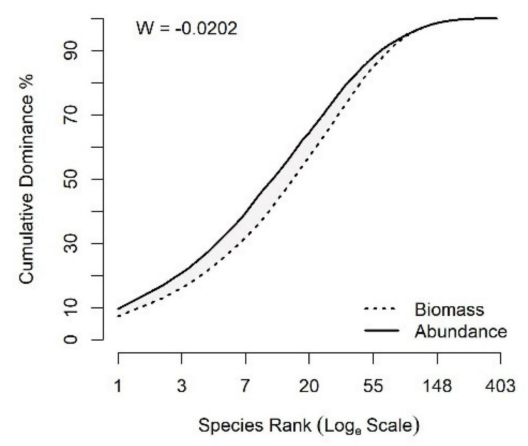

(e)

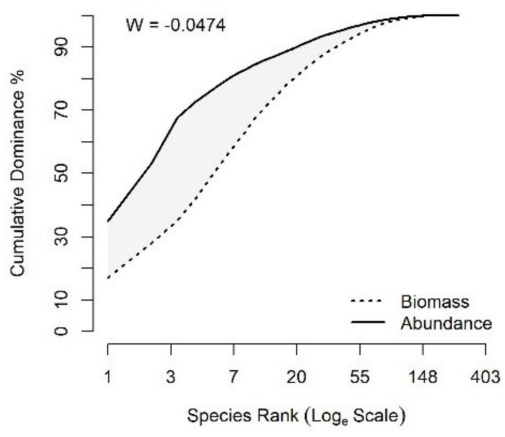

(b)

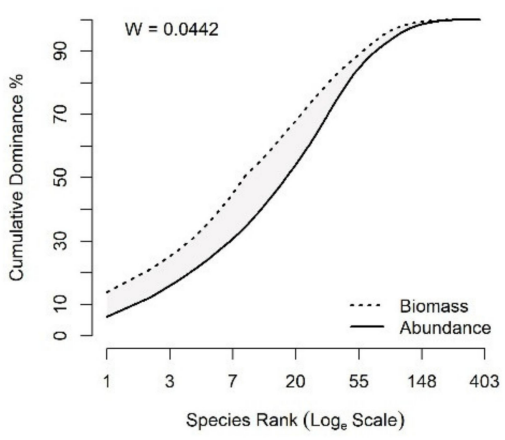

(d)

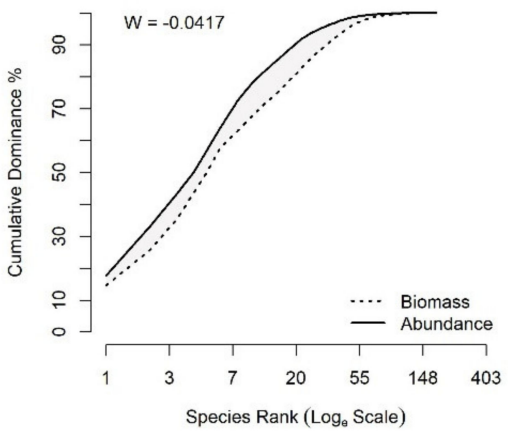

(f)

Figure 4. Cont. 


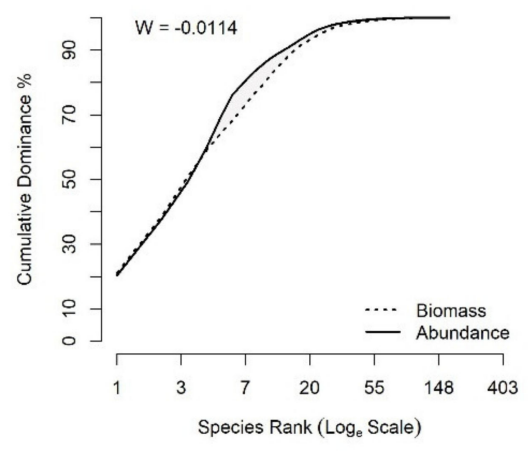

(g)

Figure 4. Comparison of abundance and biomass curves by group: (a) group 1a, (b) group 1b, (c) group $2 a$, (d) group $2 b,(\mathbf{e})$ group $3 a,(\mathbf{f})$ group $3 b$, and (g) group 4.

\section{Discussion}

\subsection{Fish Diversity in the $L M B$}

In this study, long-term time-series data of major habitats in the LMB, which documented 571 fish species, was used. The study confirmed that Cyprinidae was the most dominant family, and this aligns with previous studies [30,58-60].

The lowest level of richness was found in the upper LMB (subgroup 1a), while the highest level was found in the lower LMB (subgroup $2 b$ and subgroup $3 a$ ). This phenomenon is a common upstream-downstream gradient in fish richness since the upper LMB has a higher slope with fast and variable flowing water, while the lower LMB has larger surrounding floodplains and diverse habitats for various fish species [61-64]. Additionally, the linkage between rivers, floodplains, and tributaries in the lower LMB can enhance more foods and nutrients for numerous fishes $[65,66]$. For instance, subgroup 3a within a very large floodplain area in South-East Asia (Tonle Sap floodplain) is characterized by various species from eight fish guilds (Table S3), of which estuarine and marine fishes also occur. Similarly, previous studies also reported that estuarine or marine fish could migrate further upstream to Tonle Sap floodplain and to Khone Falls on the border between Lao PDR and Cambodia [60].

\subsection{Fish Community Structure and Its Ecological Status}

SOM and hierarchical clustering were used to partition the fish communities into four main groups reflecting the upstream-downstream gradient, which is quite similar to previous findings of [30], except for the additional habitats (TSL and 3S Rivers) not studied previously. Given that SOM mainly captures the spatial patterns in this study, future studies would benefit from exploring the temporal components of the dataset. Based on the classification, fish communities were longitudinally defined as follows: group 1 in the upper and middle LMB from Luangphrabang to Champasak province in Lao PDR and Ubon Ratchathani province in Thailand; group 2 in the Mekong River below Khone Falls and $3 S$ rivers; group 3 in floodplains including Songkram floodplain, TSL, and upper VMD; and group 4 at lower VMD. The fish communities of the upper and middle LMB consisted of two subgroups (1a and $1 b)$. Subgroup 1a, located in the upper LMB, was characterized by seven indicator species under four fish guilds (Table S3), namely rhithron residents, short-distant white fishes, long-distant white fishes, and non-native species. Poulsen, et al. [67] highlighted that the Mekong River in this reach is dominated by migratory species. Consistently, B. yarrelli, D. laosensis, L. erythropterus, and P. gigas have been previously reported to occur in this reach, and they migrate upstream $[30,56,68,69]$. Among the seven indicator species, only B. yarrelli and D. laosensis appeared in the Mekong River below the Khone Falls and Sesan River (Figure S4). Subgroup $1 \mathrm{~b}$ residing in the upper and middle LMB was characterized by four indicator species from short-distant white fishes and grey fishes. Those species 
use the Mekong mainstream as a refuge, especially during the dry season, and floodplain habitats associated with the Mun, Songkhram, and Xe Bang Fai tributaries for feeding or rearing. For example, the short-distant white fish species (Bangana elegans and Helicophagus leptorhynchus) were shown to prefer a large river of the middle LMB [56,70]. Similarly, the grey fishes (Neodontobutis aurarmus and Sikukia gudgeri) are common in marshes, swamps, backwaters and flooded fields, and were previously reported in upland rivers, especially in the middle LMB along the Thai-Lao PDR border [57]. These two communities (subgroup 1a and 1b) differed by the variation in fish fauna composition, especially the disappearance of two main guilds (rhithron residents and long-distant white fishes) in subgroup $1 b$, and the spatiotemporal shift in fish communities of LPB, LPO, LVT, and LBX during the later years of monitoring from subgroup $1 \mathrm{a}$ to $1 \mathrm{~b}$. Also, the overall change in species composition over a study period ( $\mathrm{BD}_{\text {Total }}$ ) was relatively high in subgroup $1 \mathrm{~b}$, and LCBD index was significantly high in 2012 (Table S2). This may indicate a high disturbance of fish habitats for these guilds, which was observed using ABC curves for subgroup $1 \mathrm{~b}$ (Figure $4 \mathrm{~b}$ ). Various threats (e.g., irrigation, sand mining, and destructive fishing practices) have been reported to take place in these river reaches [25,68], and several hydropower dams at the upper Mekong River in China and 31 dams, including Xayaburi dam, in the upper and middle LMB (Figure 1) may be mainly responsible for the high disturbance of fish communities [71]. Particularly, the disappearance of the two guilds may have resulted from the changes in the flow of water and sediments and fragmentation in the river [72-76]. The Mekong River Commission [77] found similar results to this study, expecting that rhithron resident species and shortand long-distant white fishes could disappear due to habitat loss from impoundments. Other studies in Nam Ou and Nam Ngiep Rivers proved similarly that the habitat modification from the free-flowing river into reservoirs resulting from dams (e.g., Nam Ou 2, 5, and 6, and Nam Ngiep 1) has had negative effects on many key species, for example, Catlocarpio siamensis, Probarbus jullieni, D. laosensis, Pangasius krempfi, Anguilla marmorata, Mekongina erythrospila, and Pangasianodon hypophthalmus [68,78].

The Mekong River below the Khone Falls and 3S Rivers encompassed almost all sites from northeast Cambodia, and the fish communities in this area were split into two subgroups (2a and $2 b$ ). In subgroup 2a, five grey and estuarine fish species (Table S3) were indicative of this subgroup. Among the five indicator species, the estuarine resident (Ophisternon bengalense) showed a wide range of habitat including both fresh and brackish waters of rivers and swamps with thick muddy vegetation, and also resides in soft bottom sediments [56]. Likewise, the grey fishes (Paralaubuca barroni and $P$. riveroi) are common in large rivers, and they have been previously reported in the Mekong and $3 S$ Rivers $[79,80]$. Subgroup $2 b$ was characterized by 15 indicator fish species under six guilds, namely rhithron residents, short-distant white fishes, grey fishes, black fishes, estuarine residents, and marine visitors. Among the six guilds, rhithron residents are the most dominant guild with five species, of which Onychostoma fusiforme, O. gerlachi, Neolissochilus stracheyi, and Opsarius pulchellus commonly occur in the rapids with swift water [56], and they have also been previously recorded in the Mekong and 3S Rivers $[79,80]$. The fish communities of subgroup $2 \mathrm{~b}$ are distinct from $2 \mathrm{a}$ and group 1 through an upturn in species richness, diversity and indicator species, and with a presence of new fish guilds such as black fish and marine visitors. This reflects a rise in more diverse and suitable habitats for fishes from Sekong and Srepok Rivers, resulting in relatively high species richness [58]. Another clear difference between subgroup $2 a$ and $2 b$ can be noticed through ABC curves (Figure 4c,d), indicating that the fish community in subgroup $2 b$ is healthier than $2 a$. SOM map revealed a spatiotemporal and substantial shift in fish communities for all sites (CKD, CST, CKT, CSS and LVT) from subgroup $2 a$, illustrating degraded fish communities which well correspond to the results of the ABC curves. Also, the temporal changes of community composition (LCBD) in subgroup 2a were significant in 2016. The high disturbance reported for subgroup 2a may arise from a combination of threats, such as hydropower dams and overfishing. Indeed, several hydropower dams at the upper reaches of Sesan River have impacted flow, sediment, and water quality [7], potentially explaining the low species richness and both taxonomic and functional diversity documented in previous studies [58,81]. Similarly, Oliveira, et al. [82] revealed that fish functional traits in the Paraná River have been changed 
by long-distant migrations with superior or subterminal mouth position with pre-impoundment conditions to non-migratory species with lower mouth position with post-impoundment conditions. The change in fish functional traits with pre- and post-impoundment conditions indicate an alteration from lotic to lentic environments. Several dams were also built in the upper reaches of Sekong and Srepok in Lao PDR and Viet Nam respectively, yet these rivers have been impacted relatively little by dams. This might be a positive effect of the protected areas (PA) which these rivers flow across. For instance, Srepok River flows through large PAs, such as Lumphat, Mondulkiri, and Yok Don Pas [83], which provide intact habitats to fish populations to grow in body size and biomass. This conclusion is supported by a study on the impact assessment of protection duration (years of fishing closure) and location (distance from shore) on reef fish diversity [84]. Further, forest degradation was low in the Sekong and Srepok Basins in comparison to the Sesan Basin [85], probably due to a positive effect of the PAs. Consequently, the forests may positively affect the fish diversity in the Sekong and Srepok Rivers. Lo et al. [86] reviewed a number of studies on forests and freshwater fishes in the tropics and inferred that forests generated a heterogeneity of habitats and foods supporting various species, generally resulting in a positive relationship between fish diversity and forest cover. Besides dams, overfishing is also considered a key factor causing the decrease of various species [26]. For example, intensive fishing pressure in the Tonle Sap system, where fish are exploited across seasons, species and sizes by a variety of fishing gears, has led to changes in the fish composition over the 15-year study period. A decline in catches of the medium to large-bodied species, that tend to occupy the high trophic levels, and stability or increases in catches of small-bodied species is seen [4]. Likewise, our 12-year data analysis indicates that the small-bodied species dominate the fish caught in subgroup 2a at about $85 \%$ (Figure S3). This is consistent with "fishing down the food web" theory which assumes that harvesting tends to remove larger individuals at higher trophic levels and replaces them with smaller ones at low trophic levels [87]. Illegal fishing-including the use of fine mesh size, dynamite, poison and electrofishing, as well as fishing in conservation zones [88,89]—is also inflicting substantial damage on fish species. The illegal fishing practices (with electrofishing being identified as the greatest threat to fish populations) have been taking place, not only in subgroup $2 a$, but also throughout the LMB since they are comparatively quick and efficient in relation to the legal methods [68,90-93]. The effect of these practices is small-scale, yet wide-ranging, with a very large damaging impact on fish populations [10], especially when combined with the other threats, such as habitat loss, hydrologic changes, and environmental degradation [26].

Floodplain fish communities are divided into two subgroups (3a and 3b). Subgroup 3a covers crucial natural floodplains such as the floodplains in Songkhram and Tonle Sap, which provide diverse habitats which serve as feeding and/or spawning areas to many key fish species and other animals. This subgroup had the highest species richness and was characterized by 43 indicator species categorized into eight guilds, namely rhithron residents, short-distant white fishes, grey fishes, black fishes, estuarine residents, marine visitors, non-native species, and generalist fishes. The species with high abundance or occurrence in this subgroup appeared to be short-distant white fishes (11 species) and grey fishes (10 species) (Table S3), which share common habitats such as rivers, streams, floodplains, and lakes. For example, Albulichthys albuloides and Wallago attu (i.e., short-distant white fishes) have been reported in the rivers, streams, and lakes, especially the TSL [56,94]. Similarly, Thynnichthys thynnoides, Parachela siamensis, and P. williaminae (i.e., grey fishes) prefer large rivers, canals, oxbows, and floodplains, and have been recorded in the TSL and Songkram floodplain $[56,95,96]$. The abundance and/or high occurrence of the species from these two guilds reflects a different feature of the habitats (floodplains) for this subgroup from the abovementioned subgroups. Interestingly, we found one species (Gymnothorax tile, a marine visitor) in this subgroup, which has never been previously reported (Figure S4). However, a comprehensive taxonomic study of this species may need to be conducted to confirm its presence in freshwater in the location of 3a. Subgroup $3 b$ comprised sites mainly in the estuary in the upper VMD with heterogeneous habitats from the earlier mentioned subgroups. The habitats are also covered by floodplain, still they are strongly influenced by tide extension 
during the dry season [77]. Six indicator species from short-distant white fishes, estuarine residents, black fishes, and non-native species are significantly associated with this subgroup, and these species show their preference for floodplain, estuaries, and tidal rivers. For example, an estuarine resident (Batrachocephalus mino) and a short-distant white fish (Pseudobagarius similis) have been recorded in tidal rivers of the Mekong [56,73]. Based on species occurrences in the SOM map (Figure S4), the black fish (Macrognathus siamensis) is commonly found in the floodplains of Tonle Sap and upper VMD, and a non-native fish (Oreochromis niloticus) is found mostly in the upper VMD and upper LMB. It was reported that $O$. niloticus escaped from farms, and the catch of this species in the Mekong Delta has increased each year from 2003 to 2012 [97]. The difference between fish communities for these two subgroups ( $3 a$ and $3 b$ ) can be observed through an absence of fish species in subgroup $3 b$ under various guilds, especially those from short-distant white fishes, grey fishes, and generalist fishes. This may have arisen from unsuitable habitats, such as soil with high levels of sulfate and acidic water in canals and rice fields during the dry season [60]. Among these two subgroups, $\mathrm{BD}_{\mathrm{Total}}$ of subgroup 3a was relatively high and the LCBD indices of 2007, 2008, 2009, and 2010 contributed significantly to community composition variation within this subgroup. Yet, ABC curves of these subgroups showed similar level of disturbance (Figure 4e,f), which most likely stems from major stressors such as irrigation, sand mining, overfishing and conversion of floodplains to agriculture and aquaculture. Irrigation infrastructure in the Tonle Sap floodplain and VMD has existed for many decades [98], and such infrastructure can modify flow, degrade habitats, create barriers and cause pollution [72,99]. Furthermore, irrigation canals have displaced the wetlands, which are home to not only fish but also to other aquatic animals and plants $[8,100]$; irrigation dams also block fish migration within the floodplains, and between tributaries and floodplains [72]. Fishes can also be susceptible to overharvesting and disease due to their accumulation below barriers [101]. In addition to irrigation, sand mining is threatening the fish communities due to habitat changes and the unavailability of food. A very large volume of sand has been extracted from the Mekong River and its tributaries [102]. Jordan et al. [103] found that sand mining in the VMD has led to riverbank and coastal erosion. Likewise, indiscriminate sand mining in the Mekong River in Cambodia and tributary rivers, such as the TSL tributaries, causes the river bank collapse and adverse impacts on the ecosystem [104,105]. In turn, sand mining may negatively impact fish due to changes in physical habitat conditions [69]. Moreover, sand mining can deteriorate aquatic plants [106] and decrease the diversity and density of benthic animals $[107,108]$ that are critical for fish in terms of foods, survival, and reproduction [109]. As with group 2, overfishing is also threatening fish communities in group 3. Indeed, fishers in the LMB have increased their fishing effort to catch more fishes [90]. The Tonle Sap Authority [110] found that 51 fishing gears have been used in the TSL. Additionally, the gillnet length has been increased to $4000 \mathrm{~m}$ in TSL [111] and $3000 \mathrm{~m}$ in VMD (MRC Fisheries Database 2019). The fishers in the TSL observed changes in fish composition, with small-bodied species now dominating the ecosystem [4,112]. In line with this, small-bodied species comprised about $80 \%$ of the fish caught in both subgroups (Figure S3). Illegal fishing practices, especially electrofishing, affect these two subgroups (MRC fisher perception database, 2019) and it was reported that some fishers in the TSL fished in conservation zones [113]. Clearing of flooded forests and forest fire in the TSL and degradation of the wetlands in the VMD were also found, and this has degraded the ecosystem and lost fish habitats $[113,114]$.

In the lower VMD, the two sites relatively close to the sea were assigned to group 4, and was characterized by 39 indicator species under five guilds, specifically grey fishes, estuarine residents, anadromous fishes, marine visitors, and non-native species. Due to the influence of marine water, marine visitors (22 species), and estuarine residents (13 species) dominated this group. For example, Coilia rebentischii and C. macrognathos (e.g., marine visitors) are known to occur in coastal waters and estuaries [57]. According to the species occurrence in the SOM map (Figure S4), most fishes from these two guilds are likely confined to the lower VMD, except for a few species (e.g., C. macrognathos and Scomberomorus sinensis) which occur in the TSL and Sekong River. Interestingly, we found P. krempfi, an anadromous fish, to be the indicator species for this group. This species 
is known to make long distance migrations of at least $720 \mathrm{~km}$ from marine and brackish waters of the Mekong Delta to spawn in freshwater up to Khone Falls in southern Lao PDR, and possibly beyond $[115,116]$. Based on the occurrence map (Figure S4), this species appears in both upper LMB and VMD, and its presence has also been reported by prior studies $[68,117]$. With a high abundance of estuarine residents and marine visitors, this fish community differs from the other subgroups. The SOM analysis illustrated an unchanged pattern for fish communities of all sites (VVL and VTV) over the study period, and small-bodied species represented only about 30\% of the catch (Figure S3). However, the overall community varied among years ( $\mathrm{BD}_{\text {Total }}$ ) (Table S2), and significant differences in species compositions were observed in 2017 and 2018. Hence, this group was also disturbed (Figure $4 \mathrm{~g}$ ), which is probably caused by the same threats (i.e., irrigation, sand mining, and overfishing) as the upper VMD, as well as the clearance of mangrove forests and urbanization. In the lower VMD, Hong et al. [118] highlighted that the mangrove forests have been dramatically degraded by aquaculture farming and rapid urbanization along the coastal regions, and this may have negative impacts on fish habitats, especially refuges for juvenile fish [119].

\section{Conclusions and Recommendation}

Analysis of long-term and large-scale fisheries data identifies longitudinal (i.e., upstream-downstream) gradient of fish diversity in the LMB, and also capture the spatiotemporal variation in fish community structure, and indicator species in the LMB fish communities. Such information is crucial to inform fisheries management and conservation in this region of interest. Based on this study, the highest species richness and diversity were observed at the Tonle Sap and Songkhram floodplains (subgroup 3a) and the Mekong River below the Khone Falls and the 3S Rivers (subgroup 2b), so these subgroups deserve high priority for management and conservation. Likewise, the upper LMB (subgroup 1a) should also be considered as a high priority area for management and conservation since it harbors several endangered and long-distant migratory fishes, for example, P. gigas and P. krempfi. Additionally, a more focused, follow-up study should be conducted in the upper and middle LMB to identify which environmental factors driving the temporal change in species composition to inform fisheries management and conservation in that area as well as the whole LMB.

Based on SOM analysis of the fish communities, hydropower dams may be causing serious and irreversible impacts to the fish communities. Groups 1 and 2 (close to both mainstream and tributary dams at the upper LMB and the 3S Rivers) show altered and degraded communities, whereas groups 3 and 4 (located far from the hydropower dams) have remained mostly unchanged. Previous studies from three different regions (Mekong River in Cambodia, Ter River in Spain, and rivers in New Zealand) also showed the same pattern since the undammed fish communities experience more natural flows than the dammed communities; and importantly, dams lead to a decline in both diversity and availability of fish habitats $[1,6,55,58]$. Moreover, the cumulative effect of dams and other threats (e.g., irrigation, sand mining, and overfishing) is an increasingly serious concern that deserves management and conservation attention. Hence, we recommend that fisheries law should be strongly enforced by cracking down on all illegal fishing practices. Furthermore, sand mining should be minimized during the spawning season since the eggs and larvae are more vulnerable to the mining [120] and should be banned in conservation areas [121]. Research should also be conducted to quantify the impact of sand mining on fish communities in the LMB, which can be used to formulate science-based policies for river and fisheries management [122]. Connectivity of the river network plays a central role in shaping fish diversity, so the longitudinal and lateral connectivity should be sustained or restored [123], for example, the Cambodian Mekong and Tonle Sap Ecosystem remain connected and free-flowing, and support very diverse and interdependent fish communities. Moreover, effective fish passages should be in place when hydropower and irrigation dams are proposed and built. As mentioned earlier, there was a strong relationship between fish diversity and forest cover; it is therefore vital to restore and protect primary and riparian forests to maintain fish diversity [124,125]. We further noticed that the non-native 
species occur throughout the LMB, thus, a proper transboundary management strategy is needed to control such species before they become invasive and established in the LMB.

Supplementary Materials: The following are available online at http://www.mdpi.com/2073-4441/12/12/3522/s1. Figure S1: Sampling effort at 25 sites from 2007 to 2018. Figure S2: Top ten dominant species for years with a significant LCBD index. Figure S3: Fish relative abundance categorized by fish-bodied size per group. Figure S4: Distribution patterns of 119 indicator fish species on the SOM map. Table S1: Fish species in their ecologically distinct groups. Table S2: Beta diversity, LCBD indices per year and $p$-values (after 999 random permutations) of SOM groups and subgroups. Table S3: Indicator species identified for each SOM group in the LMB.

Author Contributions: Conceptualization, V.N., S.L. and G.G.; methodology, V.N., S.L. and G.G.; data curation, V.N.; formal analysis, V.N.; writing—original draft, V.N.; writing—review and editing, V.N., S.L., P.B.N., N.S. and G.G.; supervision, S.L. and G.G.; visualization, V.N. All authors have read and agreed to the published version of the manuscript.

Funding: This research was funded by the United States Agency for International Development (USAID)-supported project, Wonders of the Mekong (Cooperative Agreement \# AID-OAA-A-16-00057).

Acknowledgments: The authors express sincere thanks to the Mekong River Commission Secretariat for providing fish community data. We also would like to thank Fareedali Kanji for reviewing and editing the English language of this manuscript. We are grateful to Zeb Hogan for providing helpful comments and edits to the manuscript. We would like to extend our thanks to the anonymous reviewers for their contributions to revisions, useful suggestions, and advice.

Conflicts of Interest: The authors declare no conflict of interest. The opinions expressed or statements made herein are solely those of the authors and do not necessarily reflect the views of the agencies mentioned above.

\section{References}

1. Benejam, L.; Saura-Mas, S.; Bardina, M.; Solà, C.; Munné, A.; García-Berthou, E. Ecological impacts of small hydropower plants on headwater stream fish: From individual to community effects. Ecol. Freshw. Fish 2016, 25, 295-306. [CrossRef]

2. Gomes-Silva, G.; Cyubahiro, E.; Wronski, T.; Riesch, R.; Apio, A.; Plath, M. Water pollution affects fish community structure and alters evolutionary trajectories of invasive guppies (Poecilia reticulata). Sci. Total Environ. 2020, 730, 138912. [CrossRef] [PubMed]

3. McKay, S.F.; King, A.J. Potential ecological effects of water extraction in small, unregulated streams. River Res. Appl. 2006, 22, 1023-1037. [CrossRef]

4. Ngor, P.B.; McCann, K.S.; Grenouillet, G.; So, N.; McMeans, B.C.; Fraser, E.; Lek, S. Evidence of indiscriminate fishing effects in one of the world's largest inland fisheries. Sci. Rep. 2018, 8, 1-12. [CrossRef] [PubMed]

5. McCann, K.S.; Gellner, G.; McMeans, B.C.; Deenik, T.; Holtgrieve, G.; Rooney, N.; Hannah, L.; Cooperman, M.; Nam, S. Food webs and the sustainability of indiscriminate fisheries. Can. J. Fish. Aquat. Sci. 2016, 73, 656-665. [CrossRef]

6. Jellyman, P.G.; Harding, J.S. The role of dams in altering freshwater fish communities in New Zealand. N. Zeal. J. Mar. Freshw. Res. 2012, 46, 475-489. [CrossRef]

7. Oeurng, C.; Sok, T. Assessing changes in flow and water quality emerging from hydropower development and operation in the Sesan River Basin of the Lower Mekong Region. Sustain. Water Resour. Manag. 2020, 6, 1-12. [CrossRef]

8. Mekong River Commission. The Council Study: The Study on Sustainable Management and Development of the Mekong River, Including Impacts of Mainstream Hydropower Projects. Biological Resource Assessment Final Technical Report Series. Volume 1: Specialists' Report; Mekong River Commission Secretariat: Vientiane, Laos, 2017; Volume 1.

9. Penczak, T.; Kruk, A. Applicability of the abundance/biomass comparison method for detecting human impacts on fish populations in the Pilica River, Poland. Fish. Res. 1999, 39, 229-240. [CrossRef]

10. Hu, M.; Wang, C.; Liu, Y.; Zhang, X.; Jian, S. Fish species composition, distribution and community structure in the lower reaches of Ganjiang River, Jiangxi, China. Sci. Rep. 2019, 9, 10100. [CrossRef]

11. Kundu, G.K.; Islam, M.M.; Hasan, M.F.; Saha, S.; Mondal, G.; Paul, B.; Mustafa, M.G. Patterns of fish community composition and biodiversity in riverine fish sanctuaries in Bangladesh: Implications for hilsa shad conservation. Ecol. Freshw. Fish 2020, 29, 364-376. [CrossRef]

12. Stojković, M.; Milošević, D.; Simić, S.; Simić, V. Using a Fish-Based Model to Assess the Ecological Status of Lotic Systems in Serbia. Water Resour. Manag. 2014, 28, 4615-4629. [CrossRef] 
13. Barbour, M.T.; Gerritsen, J.; Snyder, B.D.; Stribling, J.B. Rapid Bioassessment Protocols for Use in Wadable Streams and Rivers: Periphyton, Benthic Macroinvertebrates, and Fish, 2nd ed.; U.S. Environmental Protection Agency: Washington, DC, USA, 1999.

14. Huang, J.; Huang, L.; Wu, Z.; Mo, Y.; Zou, Q.; Wu, N.; Chen, Z. Correlation of fish assemblages with habitat and environmental variables in a headwater stream section of Lijiang River, China. Sustainability 2019, 11, 1135. [CrossRef]

15. Das, S.K.; Chakrabarty, D. The use of fish community structure as a measure of ecological degradation: A case study in two tropical rivers of India. BioSystems 2007, 90, 188-196. [CrossRef] [PubMed]

16. Campbell, I.C. Introduction. In The Mekong Biophysical Environment of an International River Basin; Campbell, I.C., Ed.; Elsevier Academic Press: Amsterdam, The Netherlands, 2009; ISBN 978-0-12-374026-7.

17. Mittermeier, R.A.; Turner, W.R.; Larsen, F.W.; Brooks, T.M.; Gascon, C. Global Biodiversity Conservation: The Critical Role of Hotspots. In Biodiversity Hotspots; Zachos, F., Habel, C., Eds.; Springer: Berlin/Heidelberg, Germany, 2011; pp. 3-22. ISBN 978-3-642-20991-8.

18. Ng, T.H.; Jeratthitikul, E.; Sutcharit, C.; Chhuoy, S.; Pin, K.; Pholyotha, A.; Siriwut, W.; Srisonchai, R.; Hogan, Z.S.; Ngor, P.B. Annotated checklist of freshwater molluscs from the largest freshwater lake in Southeast Asia. Zookeys 2020, 2020, 107-141. [CrossRef]

19. Sor, R.; Ngor, P.B.; Boets, P.; Goethals, P.L.M.; Lek, S.; Hogan, Z.S.; Park, Y. Patterns of Mekong Mollusc Biodiversity: Identification of Emerging Threats and Importance to Management and Livelihoods in a Region of Globally Significant Biodiversity and Endemism. Water 2020, 12, 2619. [CrossRef]

20. Ngor, P.B.; Sor, R.; Prak, L.H.; So, N.; Hogan, Z.S.; Lek, S. Mollusc fisheries and length-weight relationship in Tonle Sap flood pulse system, Cambodia. Ann. Limnol. 2018, 54. [CrossRef]

21. Mekong River Commission. State of the Basin Report 2018; Mekong River Commission Secretariat: Vientiane, Laos, 2018.

22. Jézéquel, C.; Tedesco, P.A.; Bigorne, R.; Maldonado-Ocampo, J.A.; Ortega, H.; Hidalgo, M.; Martens, K.; Torrente-Vilara, G.; Zuanon, J.; Acosta, A.; et al. A database of freshwater fish species of the Amazon Basin. Sci. Data 2020, 7, 1-9. [CrossRef]

23. Harrison, I.J.; Brummett, R.; Stiassny, M.L.J. Congo River Basin. In The Wetland Book; Finlayson, C., Milton, G., Prentice, R., Davidson, N., Eds.; Springer: Dordrecht, The Netherlands, 2018.

24. Mekong River Commission. Report on the 2015 Biomonitoring Survey of the Lower Mekong River and Selected Tributaries; Mekong River Commission Secretariat: Vientiane, Laos, 2019.

25. Bravard, J.-P.; Goichot, M.; Gaillot, S. Geography of Sand and Gravel Mining in the Lower Mekong River. EchoGéo 2013, 26. [CrossRef]

26. Allan, J.D.; Abell, R.; Hogan, Z.; Revenga, C.; Taylor, B.W.; Welcomme, R.L.; Winemiller, K. Overfishing of Inland Waters. Bioscience 2005, 55, 1041. [CrossRef]

27. Arias, M.E.; Holtgrieve, G.W.; Ngor, P.B.; Dang, T.D.; Piman, T. Maintaining perspective of ongoing environmental change in the Mekong floodplains. Curr. Opin. Environ. Sustain. 2019, 37, 1-7. [CrossRef]

28. Xie, J.Y.; Tang, W.J.; Yang, Y.H. Fish assemblage changes over half a century in the Yellow River, China. Ecol. Evol. 2018, 8, 4173-4182. [CrossRef] [PubMed]

29. Yemane, D.; Field, J.G.; Leslie, R.W. Exploring the effects of fishing on fish assemblages using Abundance Biomass Comparison (ABC) curves. ICES J. Mar. Sci. 2005, 62, 374-379. [CrossRef]

30. Chea, R.; Lek, S.; Ngor, P.; Grenouillet, G. Large-scale patterns of fish diversity and assemblage structure in the longest tropical river in Asia. Ecol. Freshw. Fish 2017, 26, 575-585. [CrossRef]

31. Mekong River Commission. Overview of the Hydrology of the Mekong Basin; Mekong River Commission: Phnom Penh, Cambodia, 2005.

32. Mekong River Commission. Monitoring Fish Abundance and Diversity in the Lower Mekong Basin: Methodological Guidelines; Mekong River Commission: Phnom Penh, Cambodia, 2007.

33. Ngor, P.B.; Hortle, K.G.; So, N. Standard Sampling Procedures for Fish Abundance and Diversity Monitoring in the Lower Mekong Basin; Mekong River Commission Secretariat: Phnom Penh, Cambodia, 2016.

34. Kohonen, T. MATLAB Implementations and Applications of the Self-Organizing Map; Unigrafia Oy: Helsinki, Finland, 2014; ISBN 9789526036786.

35. Brosse, S.; Giraudel, J.L.; Lek, S. Utilisation of non-supervised neural networks and principal component analysis to study fish assemblages. Ecol. Modell. 2001, 146, 159-166. [CrossRef] 
36. Giraudel, J.L.; Lek, S. A comparison of self-organizing map algorithm and some conventional statistical methods for ecological community ordination. Ecol. Modell. 2001, 146, 329-339. [CrossRef]

37. Park, S.H.; Hosoishi, S.; Ogata, K.; Kuboki, Y. Clustering of ant communities and indicator species analysis using self-organizing maps. Comptes Rendus Biol. 2014, 337, 545-552. [CrossRef]

38. Kohonen, T. Self-Organazing Maps, 3rd ed.; Springer: Berlin, Germany, 2001; ISBN 9783540679219.

39. Vesanto, J. SOM Implementation in SOM Toolbox. SOM Toolbox Online Help. Available online: http: //www.cis.hut.fi/projects/somtoolbox/documentation/somalg.shtml (accessed on 1 January 2020).

40. Wehrens, R.; Buydens, L.M.C. Self- and super-organizing maps in R: The kohonen package. J. Stat. Softw. 2007, 21, 1-19. [CrossRef]

41. Ludwig, J.A.; Reynolds, J.F. Statistical Ecology, a Primer on Methods and Computing; John Wiley \& Sons: Hoboken, NJ, USA, 1988.

42. Gotelli, N.J.; Colwell, R.K. Quantifying biodiversity: Procedures and pitfalls in the measurement and comparison of species richness. Ecol. Lett. 2001, 4, 379-391. [CrossRef]

43. Hsieh, T.C.; Ma, K.H.; Chao, A. iNEXT: An R package for rarefaction and extrapolation of species diversity (Hill numbers). Methods Ecol. Evol. 2016, 7, 1451-1456. [CrossRef]

44. Cox, K.D.; Black, M.J.; Filip, N.; Miller, M.R.; Mohns, K.; Mortimor, J.; Freitas, T.R.; Greiter Loerzer, R.; Gerwing, T.G.; Juanes, F.; et al. Community assessment techniques and the implications for rarefaction and extrapolation with Hill numbers. Ecol. Evol. 2017, 7, 11213-11226. [CrossRef]

45. Legendre, P.; Gallagher, E.D. Ecologically meaningful transformations for ordination of species data. Oecologia 2001, 129, 271-280. [CrossRef] [PubMed]

46. Legendre, P.; De Cáceres, M. Beta diversity as the variance of community data: Dissimilarity coefficients and partitioning. Ecol. Lett. 2013, 16, 951-963. [CrossRef] [PubMed]

47. Dray, S.; Bauman, D.; Blanchet, F.G.; Borcard, D.; Clappe, S.; Guenard, G.; Jombart, T.; Larocque, G.; Legendre, P.; Madi, N.; et al. Adespatial: Multivariate multiscale spatial analysis. Cran. 2020. Available online: https://cran.r-project.org/web/packages/adespatial/index.html (accessed on 1 January 2020).

48. Dufrêne, M.; Legendre, P. Species assemblages and indicator species: The need for a flexible asymmetrical approach. Ecol. Monogr. 1997, 67, 345-366. [CrossRef]

49. De Cáceres, M.; Legendre, P. Associations between species and groups of sites: Indices and statistical inference. Ecology 2009, 90, 3566-3574. [CrossRef]

50. De Cáceres, M.; Legendre, P.; Moretti, M. Improving indicator species analysis by combining groups of sites. Oikos 2010, 119, 1674-1684. [CrossRef]

51. Warwick, R.M. A new method for detecting pollution effect on macrobenthic communitries. Mar. Biol. 1986, 92, 557-562. [CrossRef]

52. Coeck, J.; Vandelannoote, A.; Yseboodt, R.; Verheyen, R.F. Use of the abundance/biomass method for comparison of fish communities in regulated and unregulated lowland rivers in Belgium. Regul. Rivers Res. Manag. 1993, 8, 73-82. [CrossRef]

53. Clarke, K.R.; Gorley, R.; Sommerfield, P.J.; Warwick, R.M. Change in Marine Communities: An Approach to Statistical Analysis and Interpretation, 3rd ed.; PRIMER-E: Plymouth, UK, 2014.

54. Aluizio, R. Foraminifera and Community Ecology Analyses. 2015. Available online: https://rdrr.io/cran/ forams/ (accessed on 1 January 2020).

55. Ngor, P.B.; Oberdorff, T.; Phen, C.; Baehr, C.; Grenouillet, G.; Lek, S. Fish assemblage responses to flow seasonality and predictability in a tropical flood pulse system. Ecosphere 2018, 9. [CrossRef]

56. MFD. Mekong Fish Database: A Taxonomic Fish Database for the Mekong Basin; MFD: Phnom Penh, Cambodia, 2003.

57. Froese, R.; Pauly, D. FishBase. World Wide Web Electronic Publication. Available online: www.fishbase.org (accessed on 1 January 2020).

58. Ngor, P.B.; Legendre, P.; Oberdorff, T.; Lek, S. Flow alterations by dams shaped fish assemblage dynamics in the complex Mekong-3S river system. Ecol. Indic. 2018, 88, 103-114. [CrossRef]

59. Ngor, P.B.; Grenouillet, G.; Phem, S.; So, N.; Lek, S. Spatial and temporal variation in fish community structure and diversity in the largest tropical flood-pulse system of South-East Asia. Ecol. Freshw. Fish 2018, 27, 1087-1100. [CrossRef]

60. Valbo-Jorgensen, J.; Coates, D.; Hortle, K.G. Fish diversity in the Mekong River Basin. In The Mekong Biophysical Environment of an International River Basin; Cambel, C.I., Ed.; Elsevier Academic Press: Amsterdam, The Netherlands, 2009; pp. 162-185. 
61. Welcomme, R.L. River Fisheries; Technical Paper No. 262; FAO: Rome, Italy, 1985.

62. Oberdorff, T.; Dias, M.S.; Jézéquel, C.; Albert, J.S.; Arantes, C.C.; Bigorne, R.; Carvajal-Valleros, F.M.; De Wever, A.; Frederico, R.G.; Hidalgo, M.; et al. Unexpected fish diversity gradients in the Amazon basin. Sci. Adv. 2019, 5, 1-10. [CrossRef] [PubMed]

63. Grenouillet, G.; Pont, D.; Hérissé, C. Within-basin fish assemblage structure: The relative influence of habitat versus stream spatial position on local species richness. Can. J. Fish. Aquat. Sci. 2004, 61, 93-102. [CrossRef]

64. Suvarnaraksha, A.; Lek, S.; Lek-Ang, S.; Jutagate, T. Fish diversity and assemblage patterns along the longitudinal gradient of a tropical river in the Indo-Burma hotspot region (Ping-Wang River Basin, Thailand). Hydrobiologia 2012, 694, 153-169. [CrossRef]

65. Klein, J.P.; Vanderpoorten, A. Bryophytic vegetation in riparian forests: Their use in the ecological assessment of the connectivity between the Rhine and its floodplain (Alsace, France). Glob. Ecol. Biogeogr. Lett. 1997, 6, 257-265. [CrossRef]

66. Reid, M.A.; Reid, M.C.; Thoms, M.C. Ecological significance of hydrological connectivity for wetland plant communities on a dryland floodplain river, MacIntyre River, Australia. Aquat. Sci. 2016, 78, 139-158. [CrossRef]

67. Poulsen, A.F.; Ouch, P.; Sinthavong, V.; Ubolratana, S.; Nguyen, T.T. Fish Migrations of the Lower Mekong River Basin: Implications for Development, Planning and Environmental Management; Mekong River Commission Secretariat: Phnom Penh, Cambodia, 2002.

68. International Finance Corporation. Nam Ou River Basin Profile; International Finance Corporation: Washington, DC, USA, 2017.

69. Hogan, Z. A Mekong Giant: Current Status, Threats and Preliminary Conservation Measures for the Critically Endangered Mekong Giant Catfish; WWF-Great Mekong: Bangkok, Thailand, 2012.

70. Kottelat, M. The fishes of the Nam Theun and Xe Bangfai drainages, Laos. Hydroecologie Appl. 2015, 19, 271-320. [CrossRef]

71. Mekong River Commission. Modelling the Impacts of Climate Change and Development Infrastructure on Mekong Flow, Sediment Regimes and Water Quality; Mekong River Commission Secretariat: Vientiane, Laos, 2018; Volume 1.

72. Baran, E.; Starr, P.; Kura, Y. Influence of Built Structures on Tonle Sap Fisheries; Cambodia National Mekong Committee and the WordFish Center: Phnom Penh, Cambodia, 2007.

73. Van Binh, D.; Kantoush, S.; Sumi, T. Changes to long-term discharge and sediment loads in the Vietnamese Mekong Delta caused by upstream dams. Geomorphology 2020, 353, 107011. [CrossRef]

74. Grumbine, R.E.; Xu, J. Mekong hydropower development. Science 2011, 332, 178-179. [CrossRef]

75. Kummu, M.; Lu, X.X.; Wang, J.J.; Varis, O. Basin-wide sediment trapping efficiency of emerging reservoirs along the Mekong. Geomorphology 2010, 119, 181-197. [CrossRef]

76. Kummu, M.; Varis, O. Sediment-related impacts due to upstream reservoir trapping, the Lower Mekong River. Geomorphology 2007, 85, 275-293. [CrossRef]

77. Mekong River Commission. Thematic Report on the Positive and Negative Impacts of Hydropower Development on the Social, Environmental, and Economic Conditions of the Lower Mekong River Basin; Mekong River Commission Secretariat: Vientiane, Laos, 2017.

78. Asian Development Bank. Environmental Monitoring Report for Second Quarter of 2018; Asian Development Bank: Mandaluyong, Philippines, 2018.

79. Baran, E.; Samadee, S.; Jiau, T.S.; Tran, T.C. Fish and Fisheries in the Sesan, Sekong and Srepok River Basins (Mekong Watershed), with Special Reference to the Sesan River; ICEM-International Centre for Environmental Management: Hanoi, Vietnam, 2013.

80. Benzuijen, M.R.; Timmins, R.; Seng, T. Biological Surveys of the Mekong River between Kratie and Stung Treng Towns, Northeast Cambodia, 2006-2007; WWF-Great Mekong-Cambodia Country Programme, Cambodia Fisheries Administration and Cambodia Forestry Administration: Phnom Penh, Cambodia, 2007.

81. Montaña, C.G.; Ou, C.; Keppeler, F.W.; Winemiller, K.O. Functional and trophic diversity of fishes in the Mekong-3S river system: Comparison of morphological and isotopic patterns. Environ. Biol. Fishes 2020, 103, 185-200. [CrossRef]

82. Oliveira, A.G.; Baumgartner, M.T.; Gomes, L.C.; Dias, R.M.; Agostinho, A.A. Long-term effects of flow regulation by dams simplify fish functional diversity. Freshw. Biol. 2018, 63, 293-305. [CrossRef]

83. Mekong River Commission. Planning Atlas of the Lower Mekong River Basin; Mekong River Commission Secretariat: Vientiane, Laos, 2011. 
84. Anticamara, J.A.; Zeller, D.; Vincent, A.C.J. Spatial and temporal variation of abundance, biomass and diversity within marine reserves in the Philippines. Divers. Distrib. 2010, 16, 529-536. [CrossRef]

85. Constable, D. Atlas of the 3S Basins; IUCN: Bangkok, Thailand, 2015.

86. Lo, M.; Reed, J.; Castello, L.; Steel, E.A.; Frimpong, E.A.; Ickowitz, A. The Influence of Forests on Freshwater Fish in the Tropics: A Systematic Review. Bioscience 2020, 70, 404-414. [CrossRef]

87. Pauly, D.; Christensen, V.; Dalsgaard, J.; Froese, R.; Torres, F. Fishing down marine food webs. Science 1998, 279, 860-863. [CrossRef]

88. Nuon, V.; Gallardob, W. Perceptions of the local community on the outcome of community fishery management in Krala Peah village, Cambodia. Int. J. Sustain. Dev. World Ecol. 2011, 18. [CrossRef]

89. Ounboundisane, S.; Loury, E.; Chamsinh, B.; Guegan, F. Status Report on Fish Conservation Zones in Laos; FISHBIO: Vientiane, Laos, 2019.

90. Mekong River Commission. Transboundary Fisheries Management Issues in the Mekong and Sekong Rivers of Cambodia and Laos; Mekong River Commission Secretariat: Vientiane, Laos, 2017.

91. Pawaputanon, O.; Mahasarakarm, N. An introduction to the Mekong Fisheries of Thailand; Mekong River Commission Secretariat: Vientiane, Laos, 2007.

92. Dieu, V.L. Electro fishing practices in the Srepok River Basin in central highlands, Vietnam. In Proceedings of the 10th Technical Symposium on the Mekong Fisheries, Pakse, Laos, 11-13 November 2009; Mekong River Commission Secretariat: Vientiane, Laos, 2009.

93. Campbell, T.; Pin, K.; Ngor, P.B.; Hogan, Z. Conserving mekong megafishes: Current status and critical threats in Cambodia. Water 2020, 12. [CrossRef]

94. Chan, B.; Ngor, P.B.; So, N.; Lek, S. Spatial and temporal changes in fish yields and fish communities in the largest tropical floodplain lake in Asia. Ann. Limnol. 2017, 53, 485-493. [CrossRef]

95. Rainboth, W. FAO Species Identification Field Guide for Fishery Purposes. Fishes of the Cambodia Mekong; FAO: Rome, Italy, 1996.

96. Thai Ban Research Network. Fish Species in the "Pa Bung Pa Thamm"-Local Knowledge of Fishers in the Lower Songkhram River Basin; Sustainable Biodiversity Use and Conservation in the Mekong Basin Wetlands Project, Nakhon Phanom Conservation Association and the Lower Songkhram Basin Tai Ban Research Network: Bangkok, Thailand, 2005.

97. An, V.V.; Tien, V.D.; Ngor, P.B.; Nguyen, H.S.; So, N. Exotic species in southern Viet Nam. Catch Cult. 2013, 19, 1-48.

98. Young, A. Regional Irrigation Sector Review for Joint Basin Planning Process, Regional Irrigation Sector Review for Joint Basin Planning Process; Mekong River Commission Secretariat: Vientiane, Laos, 2009.

99. Malherbe, W.; Wepener, V.; Van Vuren, J.H.J. The effect of a large-scale irrigation scheme on the fish community structure and integrity of a subtropical river system in South Africa. Ecol. Indic. 2016, 69, 533-539. [CrossRef]

100. Olson, K.R.; Wright Morton, L. Polders, dikes, canals, rice, and aquaculture in the Mekong Delta. J. Soil Water Conserv. 2018, 73, 83A-89A. [CrossRef]

101. Baumgartner, L.J. Population estimation methods to quantify temporal variation in fish accumulations downstream of a weir. Fish. Manag. Ecol. 2006, 13, 355-364. [CrossRef]

102. Piman, T.; Shrestha, M. Case Study on Sediment in the Mekong River Basin: Current State and Future Trends; Sotckholm Environment Institute: Stockholm, Sweden, 2017.

103. Jordan, C.; Tiede, J.; Lojek, O.; Visscher, J.; Apel, H.; Nguyen, H.Q.; Quang, C.N.X.; Schlurmann, T. Sand mining in the Mekong Delta revisited-current scales of local sediment deficits. Sci. Rep. 2019, 9, 1-14. [CrossRef] [PubMed]

104. Tonle Sap Authority. EIA on Mineral Resources around Tonle Sap Lake and Related Areas; Authority Tonle Sap: Phnom Penh, Cambodia, 2019.

105. Hackney, C.R.; Darby, S.E.; Parsons, D.R.; Leyland, J.; Best, J.L.; Aalto, R.; Nicholas, A.P.; Houseago, R.C. River bank instability from unsustainable sand mining in the lower Mekong River. Nat. Sustain. 2020, 3 , 217-225. [CrossRef]

106. Pitchaiah, P.S. Impacts of Sand Mining on Environment-A Review. Int. J. Geoinformatics Geol. Sci. 2017, 4, 1-6. [CrossRef]

107. Duan, X.; Wang, Z.; Tian, S. Effect of streambed substrate on macroinvertebrate biodiversity. Front. Environ. Sci. Eng. China 2008, 2, 122-128. [CrossRef] 
108. Boyd, S.E.; Limpenny, D.S.; Rees, H.L.; Cooper, K.M. The effects of marine sand and gravel extraction on the macrobenthos at a commercial dredging site (results 6 years post-dredging). ICES J. Mar. Sci. 2005, 62, 145-162. [CrossRef]

109. Diehl, S.; Kornijów, R. Influence of Submerged Macrophytes on Trophic Interactions Among Fish and Macroinvertebrates. In The Structuring Role of Submerged Macrophytes in Lakes; Jeppesen, E., Sondergaard, M., Sondergaard, M., Christoffersen, K., Eds.; Springer: New York, NY, USA, 1998; pp. 24-46.

110. Tonle Sap Authority. Technical Report on an Update of Fishing Gears in the Six Provinces around Tonle Sap Lake; Tonle Sap Authority: Phnom Penh, Cambodia, 2018.

111. Sovannara, H. Annual Report on Fisher Catch Monitoring in the Provinces around Tonle Sap Lake, Cambodia; Tonle Sap Authority: Phnom Penh, Cambodia, 2020.

112. Kc, K.B.; Bond, N.; Fraser, E.D.G.; Elliott, V.; Farrell, T.; McCann, K.; Rooney, N.; Bieg, C. Exploring tropical fisheries through fishers' perceptions: Fishing down the food web in the Tonle Sap, Cambodia. Fish. Manag. Ecol. 2017, 24, 452-459. [CrossRef]

113. Johnstone, G.; Ranjtha, P.; Fabrice, D.; Kosal, M.; Oeur, I.; Sithirith, M.; Bunna, P.; Sophat, S.; Sokheng, C.; Sochanny, H.; et al. Tonle Sap Scoping Report; CGIAR Research Program on Aquatic Agricultural Systems: Penang, Malaysia, 2013.

114. Torell, A.; Salamanca, A. Wetlands Management in Vietnam's Mekong Delta: An Overview of Pressures and Responses. In Wetlands Management in Vietnam: Issues and Perspectives; Torell, M., Salamanca, A.M., Ratner, B.D., Eds.; WorldFish: Penang, Malaysia, 2003; pp. 1-19.

115. Vu, A.; Baumgartner, L.J.; Howitt, J.; Limburg, K.; Reinhardt, J.; Mallen-Cooper, M.; Cowx, I. Connectivity of Mekong fishes between freshwater and marine habitats. Catch Cult. Environ. 2020, 26, 1-48.

116. Hogan, Z.; Baird, I.G.; Radtke, R.; Vander Zanden, M.J. Long distance migration and marine habitation in the tropical Asian catfish, Pangasius krempfi. J. Fish Biol. 2007, 71, 818-832. [CrossRef]

117. Tran, N.T.; Labonne, M.; Hoang, H.D.; Panfili, J. Changes in environmental salinity during the life of Pangasius krempfi in the Mekong Delta (Vietnam) estimated from otolith Sr: Ca ratios. Mar. Freshw. Res. 2019, 70, 1734-1746. [CrossRef]

118. Hong, H.T.C.; Avtar, R.; Fujii, M. Monitoring changes in land use and distribution of mangroves in the southeastern part of the Mekong River Delta, Vietnam. Trop. Ecol. 2019, 60, 552-565. [CrossRef]

119. Laegdsgaard, P.; Johnson, C. Why do juvenile fish utilise mangrove habitats? J. Exp. Mar. Bio. Ecol. 2001, 257, 229-253. [CrossRef]

120. Wenger, A.S.; Harvey, E.; Wilson, S.; Rawson, C.; Newman, S.J.; Clarke, D.; Saunders, B.J.; Browne, N.; Travers, M.J.; Mcilwain, J.L.; et al. A critical analysis of the direct effects of dredging on fish. Fish Fish. 2017, 18, 967-985. [CrossRef]

121. Mingist, M.; Gebremedhin, S. Could sand mining be a major threat for the declining endemic Labeobarbus species of Lake Tana, Ethiopia? Singap. J. Trop. Geogr. 2016, 37, 195-208. [CrossRef]

122. Koehnken, L.; Rintoul, M.S.; Goichot, M.; Tickner, D.; Loftus, A.C.; Acreman, M.C. Impacts of riverine sand mining on freshwater ecosystems: A review of the scientific evidence and guidance for future research. River Res. Appl. 2020, 36, 362-370. [CrossRef]

123. Shao, X.; Fang, Y.; Jawitz, J.W.; Yan, J.; Cui, B. River network connectivity and fish diversity. Sci. Total Environ. 2019, 689, 21-30. [CrossRef]

124. Wilkinson, C.L.; Yeo, D.C.J.; Tan, H.H.; Fikri, A.H.; Ewers, R.M. Land-use change is associated with a significant loss of freshwater fish species and functional richness in Sabah, Malaysia. Biol. Conserv. 2018, 222, 164-171. [CrossRef]

125. Jones, E.B.D.; Helfman, G.S.; Harper, J.O.; Bolstad, P.V. Effects of riparian forest removal on fish assemblages in southern Appalachian streams. Conserv. Biol. 1999, 13, 1454-1465. [CrossRef]

Publisher's Note: MDPI stays neutral with regard to jurisdictional claims in published maps and institutional affiliations. 